\title{
Review: A comparative study of Seagrasses species in the regional seas and QMZ
}

\author{
Ekhlas M.M.Abdelbary ${ }^{1}$ \& Aisha A.Al Ashwal ${ }^{2}$
}

\author{
${ }^{1}$ Professor, Environmental Science Center, Qatar University, Qatar (ekhlasbotany@gmail.com)
}

${ }^{2}$ Research Assistant, Environmental Science Center, Qatar University, Qatar (aalashwal@qu.edu.qa)

\section{Abstract}

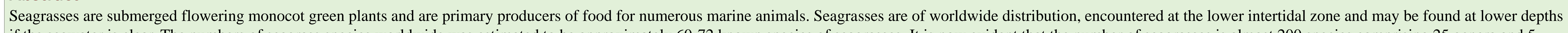

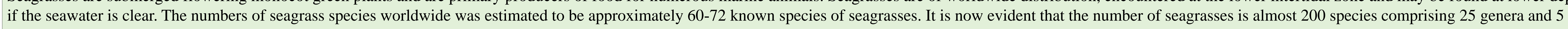
families. Of these, 10 are on the Red List; counted as risking extinction of which 3 are considered as endangered. The Western Indo-Pacific realm encompasses 13 species in two families; the Cymodoceacae with 4 genera and the Hydrocharitaceae with 3 genera. Twelve (12) species extend into the Red Sea, 4 occur in the Arabian/Persian Gulf and 4 in the Arabian Sea.

\section{Introduction}

Seagrasses are special amongst flowering plants being adapted marine life completely immersed in seawater. The distinction between seagrass species
the floral parts. The keys to the families, genera and species presented are based on a number of contributions focusing on the identity of seagrasses.

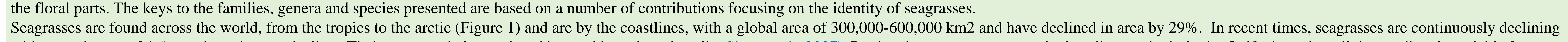

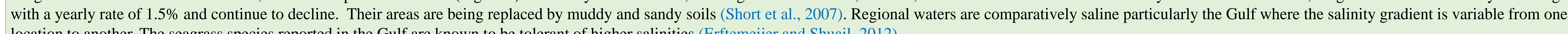
location to another. The seagrass species reported in the Gulf are known to be tolerant of higher salinities (Erftemeijer and Shuail, 2012).

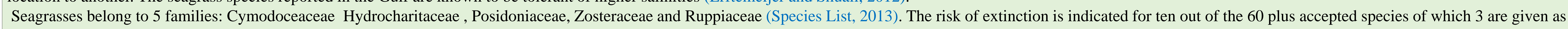
endangered (Short et al., 2011)

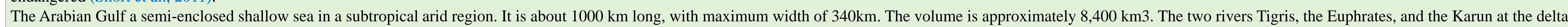

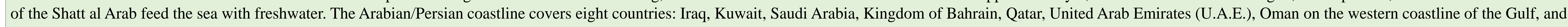

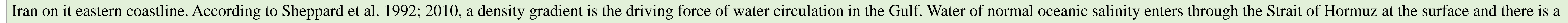

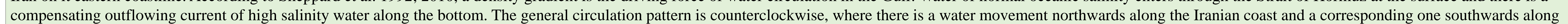

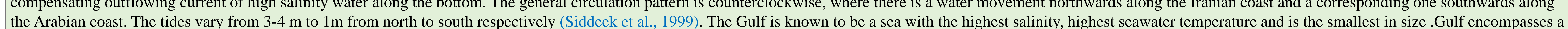
the Arabian coast. The tides vary from $3-4 \mathrm{~m}$ to $1 \mathrm{~m}$ from north to south respectively (Siddeek et al., 1999). The Gulf
surface water body of 214 x $105 \mathrm{~km} 2$ and compared to world oceans and seas, it has the least area (Ansari, 2009).

\section{Material and methodology}

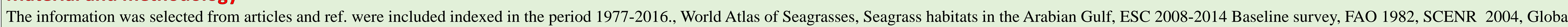

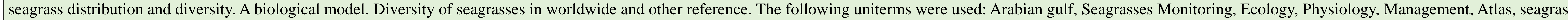

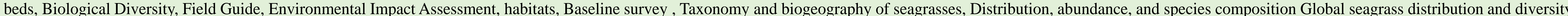
and other reference.

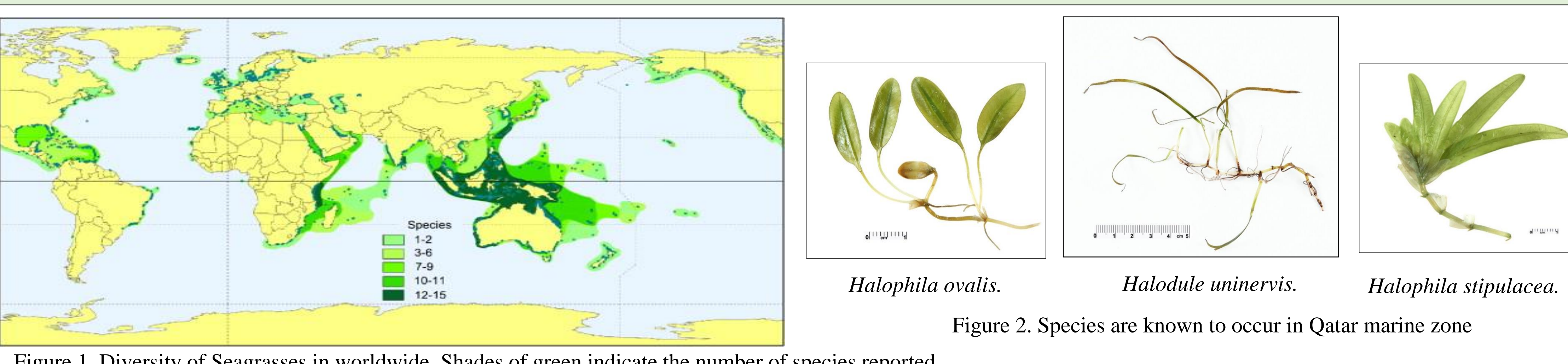

Seagrass communities

It is established that seagrasses consolidate and stabilize bottom sediments, create and maintain good water quality (clarity), produce oxygen, provide food, and nursery ground for many animals (Figure 3). Seagrasses form dense meadows in healthy locations. The seaweeds has been proven to be very important in GHG emissions Studies carried out by Greiner et al. (2013) proved the value of seagrass ecosystem as a storage of carbon and nutrients. The "blue carbon" in marine sediments is now a focus of many recent studies.

\section{Results}

*Distribution of seagrasses along the coastline of the Red Sea

The Red Sea is a long narrow basin approximately $2,000 \mathrm{~km}$ long. Twelve (12) seagrass species belonging to the seven accepted genera have been reported to occur in the Red Sea and the Gulf of Aden (UNEP, 1997; Hariri et al., 2000; Lipkin, 2003; Gaiballa, 2005; Gladstone et al., 2006; EL Shaffai, 2011) (Table 1).

*Distribution of seagrasses along the coastline of the Gulf

Seagrass meadows in the Gulf occur in nearshores and shallow waters less than $10 \mathrm{~m}$ as underwater meadows or pastures. The largest areas of seagrass beds occur off the coasts of the UAE and between the Kingdom of Bahrain and Qatar with an estimated area of 5,500 and $1,000 \mathrm{~km}^{2}$, respectively. (Table 2 ) shows occurrence of seagrass species in the Arabian/ Persian Gulf.

*Distribution of seagrasses along the coastline of Qatar

Qatar is a small low-lying limestone peninsula situated midway along the western coast of the Gulf, including a number of small offshore islands. The total coastline including the islands is over $750 \mathrm{~km}$ approximately $23 \%$ of the coasts of the Gulf with numerous bays and undulations and protrusions seawards.

The total area of Qatar marine zone (EEZ) is approximately $35,000 \mathrm{~km}^{2}$ almost $15 \%$ the Gulf area.

Three species are known to occur in Qatar marine zone at many locations on the eastern coastline. Records for the western coastline are few in limited studies (Figure 4a, b \& c).

These are Halophila stipulacea, Halophila ovalis is fairly common and Haplophila ovalis is relatively rare and Halodule uninervisis the most Common (Figure 2)

A fourth species Syringodium isoetifolium reported to occur on the western coastline (Qatar - Bahrain) apparently does not exist.
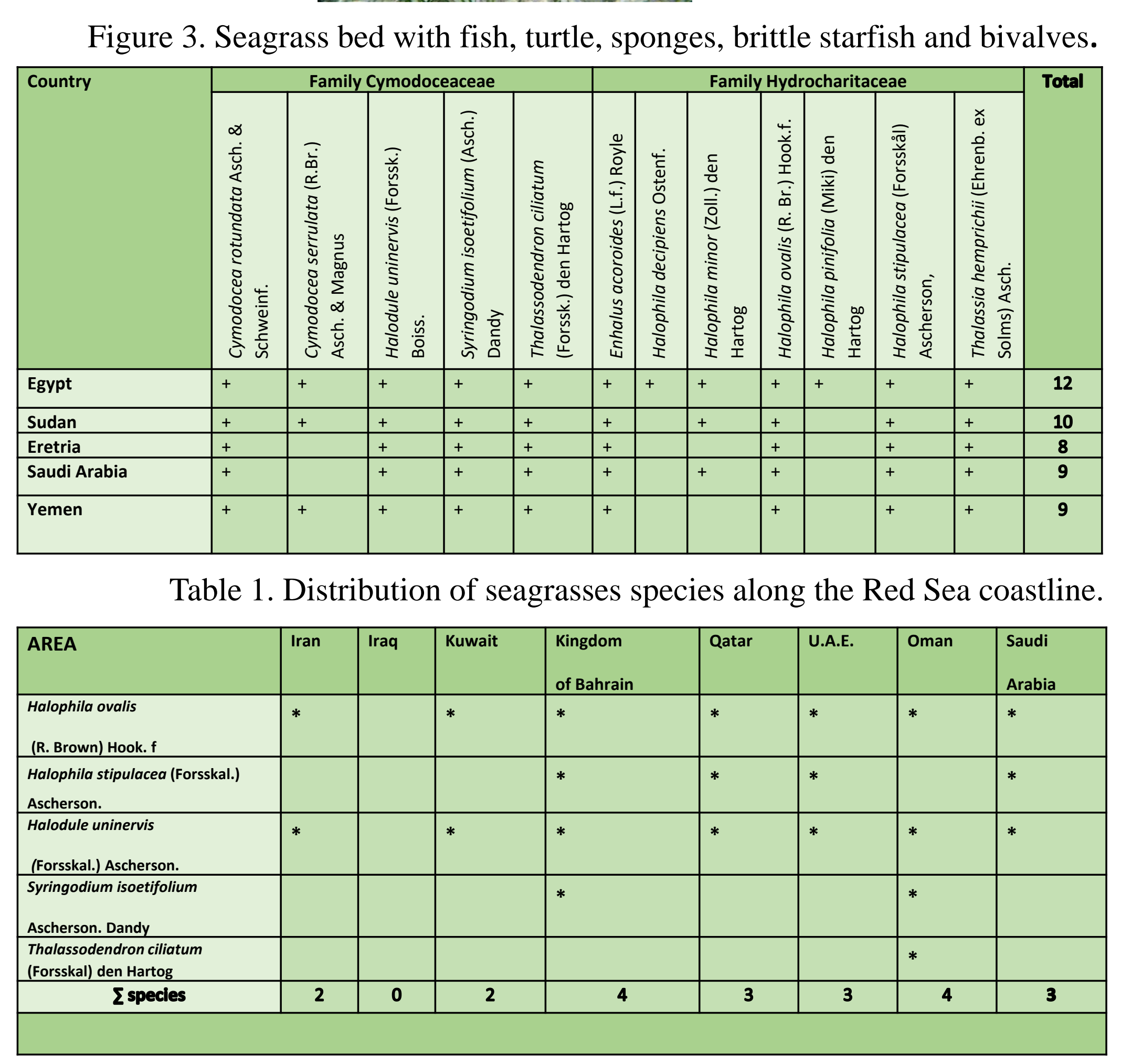

Conclusion \& Recommendations

*The three seagrass species reported to occur in Qatar Marine Zone and generally in the Gulf are tolerant of salinity. Halodule univernis is the most tolerant and it is the most common of the 3 species.

*Qatar is a fish-based diet nation similar to other Gulf countries, has the second largest population of the endangered dugongs, the engendered marine turtles feed in its waters, the Hawksbill turtles nest on Qatari coastlines.

*Both seagrasses and seaweeds are primary producers, play an important role in the control of GHG emissions.

*They are an essential habitat for a number of marine organisms and most importantly their role in food security.

*The global estimate of loss is 2-5\% floating masses of seagrass and seaweed detritus were observed and are most likely a result of dredging operations. The irresponsible net-fishing in some areas impact negatively on marine vegetation which is essential for the survival of marine organisms and the Gulf waters suffer from an anthropogenic impacts like the locations of desalination plants is a major problem for the future of the Gulf. (Figure 5\&6)

*Therefore they are diminishing and are being lost at an alarming rate. According to Short et al. (2011) 10 species are on the IUCN Red List of risk of extinction and 3 are endangered out of the estimated total number of 72 species.

Yet much more is needed to document their exact coverage in the Gulf and evidence of their value as a critical marine habitat.

*Environmentalists must embark on an active program to protect the existing

seagrass beds and to increase their diminishing cover.

*This will also be a contribution by Qatar to reduce the negative impact of climate change and towards its commitment to reduce of $\mathrm{CO} 2$ emissions from their industrial sources.

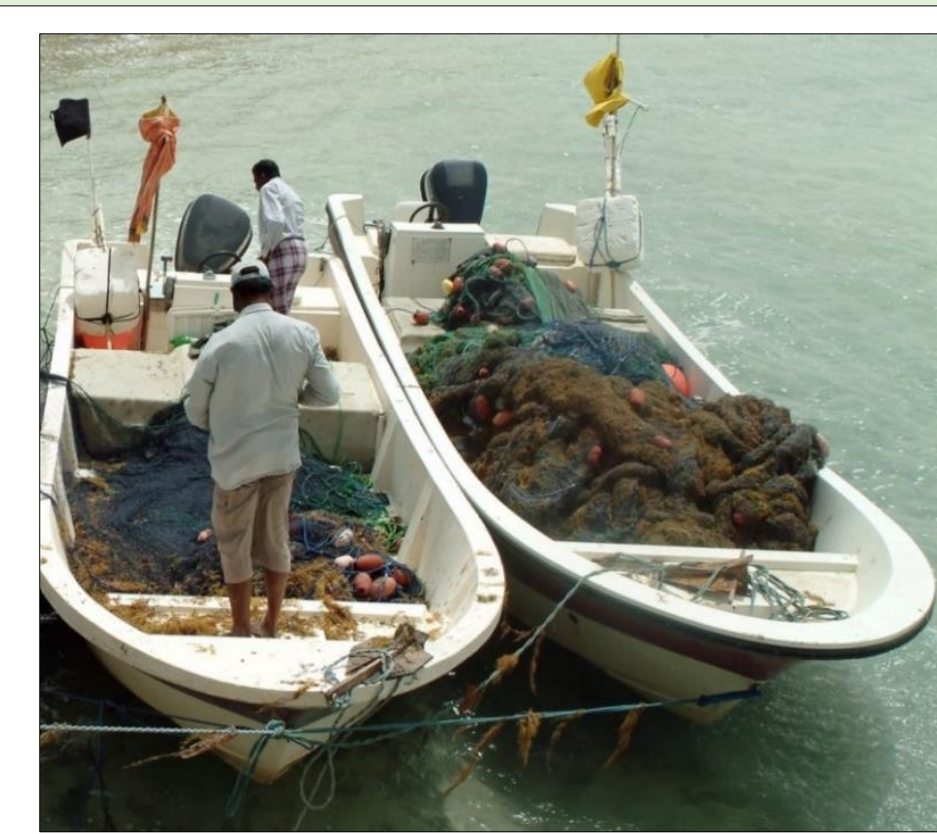

seaweeds and seagrasses in

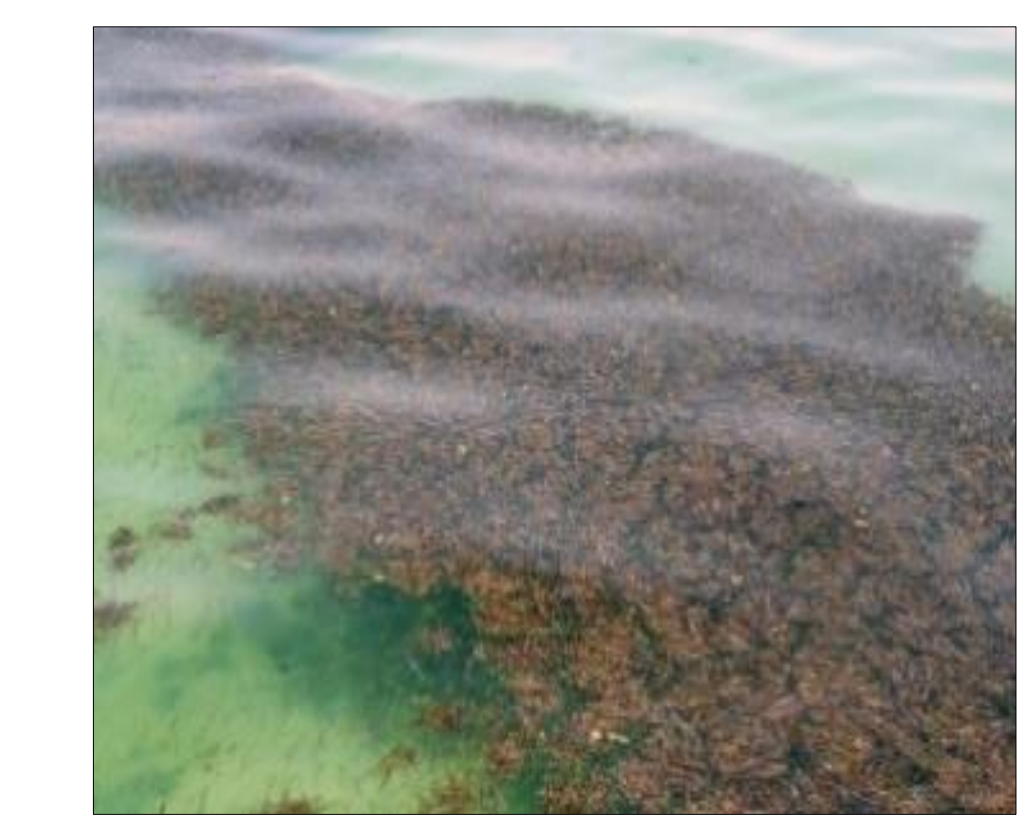

Figure 6. Drifting masses of seagrasses and seaweeds
possibly due to dredging operations on the seabed. S. QMZ

\section{Acknowledgement}

We thank Prof. Hamad Al-Saad Al-Kuwari, Director of ESC, Mrs. Hajer A Al-

Naimi the Manager of Technical Services, Dr. Sinan Husrevoglu for design the map and the Marine science lab team members.

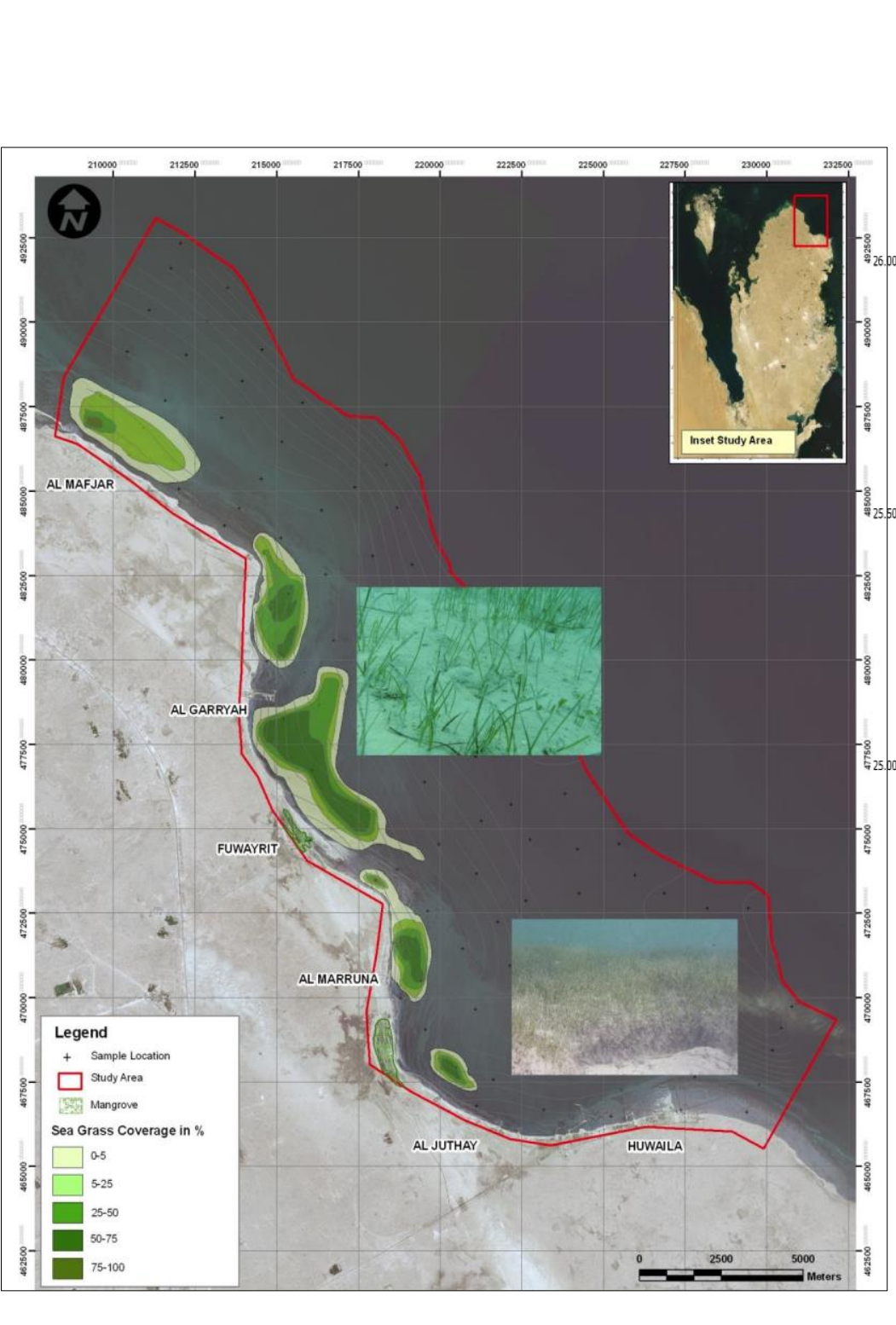
Figure 4b. Distribution and cover of
seagrasses along the eastern coastline fro N Raslaffan to S Al Mafja

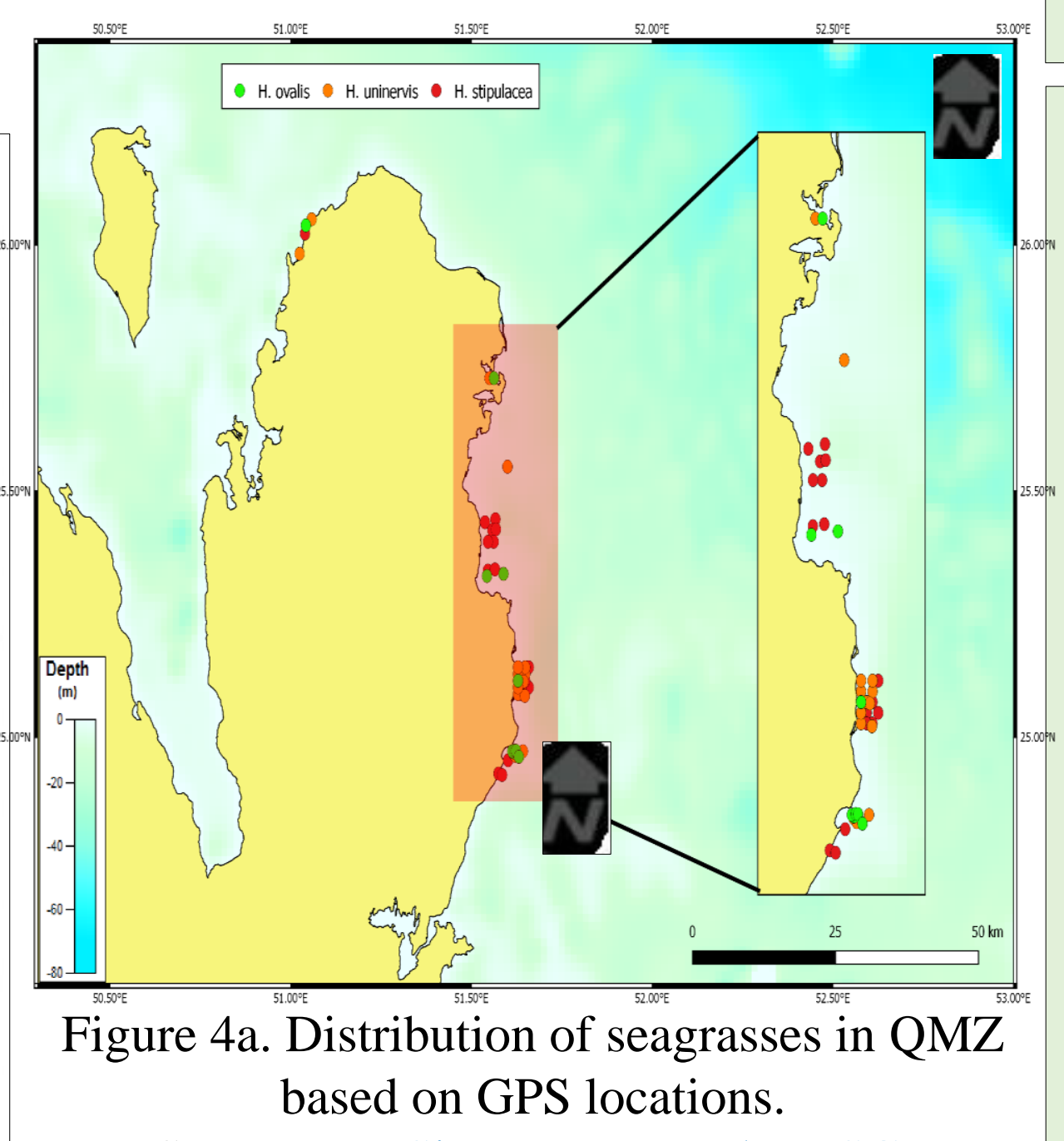

References

Al-Ansari M.A.Saleh., 2009, A hydrographic and biogeochemical study of waters and sediment of the exclusive conomic zone (EEZ) of Qatar (Arabian Gulf) University of Newcastle Upon Tyne. Thesis.

"El Shaffai A., 2011, Field Guide to seagrasses of the Red Sea. Ed. Rauphael and Abdulla A. Published by IUCN Gland, Switzerland and Total Foundation Courbevoie, France. p.55

ESC, 2010-2011, Eastern coastline north of RasLaffan and south Mafjar. Qatar University, Environmental studies center.

"Greiner J.T., McGlanthery K.J., Gunnell J., and McKee B.A., 2013, Seagrass restoration enhances “Blue Carbon" sequestration in coastal waters. PLOS ONE Tenth Anniversary, p.8.

Ertemeljer P.L.A., and Shuail D., 2012, Seagrass habitats in the Arabian Gulf: distribution, tolerance thresholds and threats. Aquatic Ecosystem Health and Management, 15:73-83

Gaiballa, A.K., 2005, Impacts of coastal development activities on seagrasses along the Sudanese Red Sea coast. MSc. thesis, University of Khartoum, p.181

*Hariri K.I., Nichols P., and Krupp F., 2000, Status of the living marine resources in the Red Sea and Gulf of Aden region and their management. Regional Organization for the Conservation of the Environment of the Red Sea and Gulf of Aden (PERSGA) Final Report, p.150,

*Lipkin Y., Beer S., and Zakai D., 2003, The Seagrasses of The eastern Mediterranean and the Red Sea. Green E.P. and Short F.T., (Eds.), World Atlas of Seagrasses.

"Sheppard C.R.C., Price A.R.C., and Roberts C.M., 1992, Marine Ecology of the Arabian Region: Patterns and Processes in Extreme Tropical Environments. Academic Press London. Vol. 8, 3: 1-359.

Short F., Camuthers T., Dennison W., and Waycott M., 2007, Global seagrass distribution and diversity. A biological model. Diversity of seagrasses in worldwide, Journal of Experiment Marine Biology and Ecology, issue 1-2. 350: 3-20. *Short F.T., et al., 2011, Extinction risk

*UNEP, PERSGA, 1997, Reg61-1971

essment of land-based sources and Activities affecting the marine of Aden. UNEP regional Seas Reports and Studies No. 166, United Nations Environment Programme, p.156. 